\title{
Love and Money, Romance and Scam
}

Desire describes a state of attachment to something or someone, and the cloud of possibility that is generated by the gap between an object's specificity and the needs and promises projected onto it. This gap produces a number of further convolutions. Desire visits you as an impact from the outside, and yet, inducing an encounter with your affects, makes you feel as though it comes from within you; this means that your objects are not objective, but things and scenes that you have invested attachment-value in, in a way that converts them into objects that prop up your world. So what seems objective and autonomous in them is partly what your desire has created and therefore is mirage, a shaky anchor. Your style of addressing those objects gives shape to the drama with which they allow you to reencounter yourself. By contrast, love is the embracing dream in which desire is reciprocated: rather than being isolating, love provides an image of an expanded self, the normative version of which is the two-as-one intimacy of the couple form.

-Lauren Berlant, "Desire" 
Mutual enjoyment is possible, for example, if you enjoy body contact and I enjoy body contact. A somewhat different type of mutual enjoyment may involve body contact but also the wish to cling to the other. The embrace is capable of being experienced as mutually rewarding if each clings to the other. The embrace also provides mutual enjoyment when each wishes to hug the other, or to hug and be hugged simultaneously, to achieve a claustral interpenetration in which each is inside the other. If each wishes to rub the skin of the other and to be stimulated in the same way at the same time, a particular type of embrace will satisfy both individuals. If each party wishes to take into his mouth, to suck or bite, some part of the body of the other, mutual enjoyment is possible so long as each does not object to the same behavior on his own body. It is possible if you enjoy looking at me and I enjoy looking at you. It is possible if you enjoy looking at me and at the same time my looking at you, and I enjoy looking at you and at the same time your looking at me; in short, our looking into each other's eyes. Mutual enjoyment on a looking basis may, as in the latter case, involve mutual awareness of what each is doing at the same time or, as in the former case, it need not involve mutual awareness. We may enjoy each others' company in the latter case with each looking at the other but without doing this simultaneously and without awareness of mutuality. Thus two people may be quite companionable each involved in reading a book and from time to time one raises his eyes and looks and smiles at the other without the other's awareness, and conversely. Adolescent loving is not infrequently carried on at a distance, with each party stealing glances at the other.

- Silvan Tomkins, Shame and Its Sisters 
Gay romance, as I have said, was much longer established than SM in Johnny and Justice's neighborhood. By the 200os, the typical pattern began with several months, sometimes longer, of Internet chatting, after which the white gay man visited Atlantic Africa as a tourist.

In that moment, two very different cultural constructions of love and money began to come into collision. And whether the wealthier and otherwise more powerful white gay man realized it or not, the balance of power tilted decisively toward his African partner. For the white man was stepping back in European time, as it were, to a social world in which homosexuality was illegal and in which blackmail and extortion were always potentialities. After any misunderstanding, it was easy for an African lover to go to the police to claim that he had been molested by a gay foreigner. The police arrested the foreigner and extorted bribes, which were shared with the young African man.

Such recourse was often understood by the African lover as just punishment for a European's taking advantage of him. According to both African and European interlocutors, young men in the ghetto were quite jealous of one another. They were ready to undermine the European relationship of another. And if their own lover did not come through with showy support, they could feel humiliated in relation to their peers. However this sense of self in relation to others eventually worked out, it was not as if Africans necessarily began with the intent to scam. Most, I would say, genuinely wanted a relationship-even if they had little idea of what such entailed from a European point of view.

Misunderstandings were built into this situation. As we have seen, the Europeans who came to Africa looking for a male sexual partner always identified as gay. But sex, for many, 
was something that could be enjoyed in and of itself, outside of any further social commitment. The same men had, of course, notions of "love," but love is defined as something deeper and more long-standing than sexual attraction, and it was typically opposed to strictly economic transactions. "Love is what money can't buy." If money intervenes too overtly in a relationship, prostitution is the category that comes to denominate itnot love.

According to my research, African men looking for a European partner brought different notions to their encounters. Though many presented themselves as "gay" on European gay social networking sites (a handful listed themselves as "bisexual"), none, as far as I can tell, understood themselves as exclusively attracted to men. Sex with a man was erotic, but that hardly meant that sex with a woman was not. Second, virtually no sex took place between an African and a European that did not involve the flow of economic resources, not as "payment," but more globally as that which constituted the relationship (Cole and Thomas 2009). "No romance without finance," as the African saying goes in relation to men and women.

Not only that, but money and the vision of escape abroad apparently also effected sexual arousal. One young informant (who claimed to have no sexual experience with men-only a kiss) said, "Desire is all in the mind. Someone may get really turned on when he is having sex just by thinking of all the things that will come his way." Almost everyone I talked to claimed that any man in the neighborhood could have male-male sex with a European. But, tellingly, more than half of my interlocutors claimed that they were turned off by the idea of sex with an African man. On the European side, I talked to one man who said that his African partner had virtually raped him on their 
first date. "But I couldn't believe it," he went on to say. "In the middle of all this hot sex, the guy turned over in bed, relaxed on the pillow, and asked me whether I could buy him a taxi!"

If money turned sex on, its lack could turn it off. Like African wives, male partners to Europeans could go on "sex strikes." They withheld sex to get what they wanted. One stopped having sex with his European partner because the latter refused to buy him another house in a better-off suburb. He wanted out of the ghetto, particularly for the future of his children. The European man, in contrast, enjoyed the difference and vitality of the ghetto.

The clash of cultural perspectives, in effect, set up a kind of filtering process for visiting Europeans. Many left disgusted. A few posted racist reactions on the profiles of those whom they believed had used them. Others ended up paying bribes to escape. But the ones who survived to establish long-term relationships had to take up para-ethnography themselves. They had to develop some appreciation of the different cultural situation in which they were operating. They also had to be generous. One European who had been visiting for years apparently ran up significant credit card debt at home in order to fund his friends in Atlantic Africa-debt he was able to pay off only when his mother died and he inherited. Another invested in a local business with his African partner to the tune of several hundred thousand dollars. 